\title{
PENGEMBANGAN BAHAN AJAR BOLA VOLI UNTUK SEKOLAH MENENGAH ATAS
}

\author{
Indah Lestari', Saifuddin', Nyak Amir' \\ Magister Pendidikan Olahraga Program Pascasarjana Universitas Syiah Kuala Banda Aceh \\ Fakultas Keguruan dan Ilmu Pendidikan Universitas Syiah Kuala Banda Aceh
}

\begin{abstract}
Penjasorkes learning at High School emphasizes the basic movements variations into games and sports, and therefore physical education sangant expect factor of the student and the student's learning external factors, it can not be separated from the role of an educator. This research aims to develop teaching materials volleyball materials for high school students. The approach in this study classified into research and development that will produce learning. Subjects in this stusy is a class XI student of State Senior High School 16 Banda Aceh of 20 people. The process of developing a measuring tool of teaching materials volleyball include (1) observation, (2) Consulting experts, (3) the design of the product, (4) validation of the design the product, (5) design revisions, (6) simulations products, (7) the revised products, (8) the trial use of the product, (9) the result of the product. From the research result are the calculated by using SPSS. The result of the studies that have been obtained on the basis of analysis and discussion, it can concluded that instrument teaching materials volleyball for high school students consisting of 13 items of questions of teaching materials that are valid and reliable to have a level of authenticity is high with the points index score validity 0.851 and has a level of reability that are the points tally reliability index score of 0.685 . Development of teaching materials so that the product can be used as teaching materials in the learning materials volleyball for High School.
\end{abstract}

Keywords: Development, Instructional Materials, Games, Volleyball

\begin{abstract}
ABSTRAK
Pembelajaran penjasorkes padamSekolah Menengah Atas menekankan pada variasi gerak dasar kedalam permainan dan olahraga, oleh sebab itu pendidikanjasmani sangat mengharapkan factor dari dalam diri siswa dan faktor eksternal belajar siswa, hal ini tidak bisa terlepas dari peran seorang pendidik. Penelitian ini bertujuan untuk mengembangkan bahan ajar materi bola voli untuk siswa Sekolah Menengah Atas. Pendekatan dalam penelitian ini tergolong kedalam penelitian pengembangan yang nantinya akan menghasilkan produk dalam pengajaran. Subjek dalam penelitian ini adlah siswa kelas XI Sekolah Menengah Atas Negeri Banda Aceh yang berjumlah 20 orang. Proses pengembangan alat ukur bahan ajar bola voli meliputi (1) Observasi, (2) Konsultasi para ahli, (3) desain produk, (4) validasi desain produk, (5) revisi desain, (6) simulasi produk, (7) revisi produk, (8) ujicoba pemakaian produk, (9) hasil produk. Dari hasil penelititan dihitung dengan menggunakan program SPSS. Hasil dari penelitian yang sudah diperoleh berdasarkan analisis dan pembahasan, maka dapat di simpulkan bahwa instrument bahan ajar materi bola voli untuk siswa Ssekolah Menengah Atas terdiri dari 13 item peertanyaan bahan ajar yang valid dan reliabel dengan memiliki tingkat kesalahan yang tinggi dengan perolehan poin indeks skor validitas 0.851 dan memiliki tingkat keterandalan yang sedang dengan perolehan idek poin skor reabilitas 0.685. Sehingga produk pengembangan bahan ajar dapat digunakan sebagai bahan ajar dalam pembelajaran materi bola voli untuk Sekolah Menengah Atas,
\end{abstract}

Kata kunci: Pengembangan, Bahan Ajar, Permainan, Bola Voli

\section{PENDAHULUAN}

Perkembangan pendidikan adalah hal yang memang seharusnya terjadi sejalan dengan perubahan budaya kehidupan. Masalah belajar merupakan hal yang sangat pokok, karena pengetahuan, keterampilan, dan sikap seseorang tersebut akan terbentuk dan berkembang apabila adanyankegiatan yang dilakukan dengan melalui proses belajar, Kegiatan jasmani selain bertujuan untuk kesehatan juga dapat meningkatkan prestasi. Prestasi olahraga dapat meningkatkan harkat hidup orang banyak bahkan dapat 
mengharumkan nama bangsa. Kegiatan olahraga merupakan bagian yang tidak terpisahkan dari semua aspek kehidupan manusia, karena kegiatan jasmani dan rohani merupakan suatu hal yang penting dalam menghadapi tantangan hidup di kegiatan sehari-hari.

Bola voli adalah cabang olahraga yang banyak digemari oleh para remaja. Melalui kegiatan bola voli, remaja memperoleh banyak manfaat, khususnya dalam hal pertumbuhan fisik, mental, dan social yang baik. Dalam bermain bola voli siswa dilatih beberapa keterampilan fisik yang berkaitan dengan pertumbuhan bagian-bagian tubuh secara wajar. Persendian-persendian menjadi baik, otot-otot menjadi kuat, peredaran darah menjadi lancer, pernapasan tidak terhambat, pikiran dilatih memecahkan masalah dengan cepat dan tepat dan sebagainya.

Cabang olahraga ini terdiri dari teknikteknik seperti pasing bawah, pasing atas, smash, servis, dan bloking, dan variasi gerak yang harus diajarkan kepada anak oleh guru pendidikan jasmani. Penguasaan gerak dalam permainan bola voli merupakan aspek penting dan dominan dalam tujuan pendidikan jasmani. Tujuan pendidikan jasmani dalam kurikulum mencakup perkembangan dan kemampuan organic, neorumuscular, intelektual, dan emosional secara menyeluruh. Kegiatan penguasaan gerak dalam pendidikan jasmani adalah gerak manusia, aktivitas jasmani yang bersifat umum.

Guru pendidikan jasmani mempunyai peranan yang sangat penting untuk membantu tercapainya kesegaran jasmani siswa, karena itu guru pendidikan jasmani harus mampu membawa sisswa kedalam situasi yang menyenangkan dalam pembelajaran. Dorongan untuk bermain pada diri siswa, bagi seorang guru pendidikan jasmani dapat digunakan dalam tindakan pendidikan selanjutnya. Dengan bentuk-bentuk permainan yang menarik akan meningkatkan motivasi siswa untuk mengikuti pembelajaran. Keberhasilan pendidikan jasmani di sekolah tentunya harus didukung beberapa faktor seperti : kecakapan guru pendidikan jasmani dalam men=mberikan bahan ajar dan eningkatkan kemauan siswa dalam mengikuti pelajaran serta tersedianya alat dan fasilitas yang memadai.

Pengembangan pembelajaran yang diperlukan saat ini adalah pembelajaran yang inovatif dan kreatif ysng mrmberikan iklim kondusif dalam pengembangan daya nalar dan kreativitas siswa. Usaha guru untuk mencapai tujuan pembelajaran antara lain memiliki metode yang tepat, sesuai dengan materinya dan menunjang terciptanya kegiatan belajar mengajar yang kondusif.

Pengembangan bahan ajar diperlukan yaitu dengan permainan net berjalan, yang dapat memberikan jalan untuk memperbaiki permasalahan yang ada pada pelaksanaan pembelajaran permainan bola voli, sehingga diharapkan kompetisi siswa baik di ranah kognitif, keterampilan maupun terhadap permainan bola voli dapat meningkat.

Pengembangan bahan ajar melalui permainan dengan net hidup ini memberikan pengalaman gerak yang baikterhadap peserta didik sangat antusias dan senang terhadap permainan bola voli.

Dari uraian di atas, peneliti tertarik untuk mengadakan penelitian dengan masalah pengembangan bahan ajar permainan bola voli, sebagai wahana pemelajaran penjasorkes yang inovatif, untuk memberikan pembelajaran yang lebih menarik dan menyenangkan, yang sekaligus bermanfaat bagi perkembangan dan pertumbuhan peserta didik dan tujuan utama dari modifikasi permainan yaitu meningkatkan aktivitas gerak pada siswa. Diharapkan pembelajaran melalui pengembangan bahan ajar ini dapat meningkatkan hasil belajar dalam permainan bola voli. Sehingga hasil dari penelitan ini dapat digunakan sebagai pertimbangan untuk pemilihan metode pembelajaran yang tepat pada materi maupun untuk bidang studi lainnya.

Berdasarkan pokok masalah yang telah penulis uraikan, maka penulis ingin melakukan penelitian yang berhubungan dengan bagaimana cara agar siswa SMA Negeri 16 Kota Banda Aceh menjadi lebih efekif dan guru dapat mengembangkan bahan ajar terhadap pembelajaran jasmani di sekolah. Jadi penulis menetapkan judul "Pengembangan Bahan Ajar Permainan Bola Voli Untuk SMA Negeri 16 Kota Banda Aceh".

\section{KERANGKA TEORITIS Pengertian Pengembangan}

Menurut Thomlinson

Pengembangan adalah apa yang dilakukan oleh seorang penulis, guru atau siswa untuk bisa merubah sesuatu ke arah yang lebih baik. Pengembangan sangat diperlukan dalam berbagai bidang salah satunya dalam bidang pendidikan. Pengembangan sangat diperlukan untuk mencapai tujuan pendidikan salah satunya 
yaitu: mampu menciptakan sumberdaya manusia yang produktif. Guru orang yang sangat berperan dalam menciptakan dan menyiapkan sumber daya manusia yang lebih baik. Pendidik harus mampu mengembangkan bahan ajar yang disesuaikan dengan tingkat pendidikannya. Semakin tinggi tingkat pendidikan, maka guru dituntut untuk semakin kreatif dalam mengembangkan bahan ajar. Pengembangan bahan ajardapat menciptakan suasana baru peserta didik, sehingga peserta didi tertarik dan mau berperan aktif bagi dalam pembelajaran.

Kamus Besar Bahasa Indonesia karya Poerwodarminto ( 2003:473), bahwa pengembangan adalah perbuatan menjadikan bertambah, merubah sempurna pikiran, pengetahuan dan sebagainya. Pengembangan merupakan suatu proses perubahan perbuatan yang bertujuan untuk menghasilkan sesuatu secara efektif khususnya dalam pembelajaran. Tujuan ini akan tercapai apabila seorang guru mampu mengembangkan bahan ajar. Salah satu bahan ajar untuk anak Sekolah Menengah Atas yaitu bahan ajar materi bola voli.

Guru pendidikan jasmani diharuskan untuk mengembangkan suatu bahan ajar dengan mempertimbangkan kondisi perkembangan gerak peserta didik. Guru pendidikan jasmani di sekolah harus mampu mengembangkan bahan ajar agar peserta didik tertarik utnuk mengikuti pembelajaran. Bahan ajar yang dirancang haruslah sesuai dengan karakterisrik para siswa agar peserta didik tidak mudan bosan dan senang melakukannya sehingga akan mampu untuk mengembangkan gerak fundamental yang ada pada setiap peserta didik, sesuai dengan pendapat Arikunto ( 1994:1 ), bahwa kurikulum adalah seluruh pengalaman yang dikembangkan dan dipersiapkan bagi peserta didik untuk mengatasi situasi kehidupan dengan bimbingan kehidupan.

Berdasarkan pendapat di atas maka dapat penulis simpulkan bahwa pengembangan itu merupakan pengembangan komponen kurikulum yang berbentuk system itu sendiri, yaitu tujuan, bahan, metode, peserta didik, pendidik, media dan lingkungan. Dengan kata lain pengembangan bahan ajar merupakan salah satu bagian bagian dalam usaha pengembangan kurikulum secara keseluruhan. Idealnya beberapa komponen memiliki peluang untuk dikembangkan, akan tetapi banyak hal juga yang harus diperhitungkan, misalnya pengembangan bahan ajar dan pembelajarannya perlu disesuaikan dengan kebutuhan siswa.

\section{Bentuk Pengembangan}

1 Bentuk J.E. Kemp

Kemp (dalam muhaimin 2002:222), lebih berpijak pada empat unsur dasar perencanaan pembelajaran. Empat unsur dasar ini merupakan wujud jawaban atas pertanyaan: 1) untuk siapa suatu program itu dirancang (peserta didik); 2) kemampuan apa yang ingin anda pelajari (tujuan); 3) bagaimana isi pelajaran dapat dipelajaru (metode); dan 4) bagaimana anda menentukan tingkat penguasaan pelajaran yang sudah dicapai (evaluasi).

Setiap langkah pengembangan, kemungkinan ada kesalahan-kesalahan, sehingga membutuhkan revisi semua unsur yang terdapat dalam diagram tersebut. Pada bentuk Kemp, seorang pengembang dapat memulai proses pengembangan dari proses manapun. Kurikulum berlaku secara Nasional di Indonesia berorientasi pada tujuan, maka seyogyanya proses pengembangan itu dapat dimulai dari tujuan. Sebagai kelebihan dari bentuk ini adalah urutan prosudur pengembangannyadan tidak kaku, karena pengembangan pengajaran dapat dimulai dari mana saja. Sedangkan kelemahannya adalah tidak ada kejelasan tentang apa yang dilakukan pada langkahlangkah yang berhubungan pada ketentuan aktifitas belajar mengajar, serta pemilihan dan pemakaian sumber belajar yang tepat dan sesuai.

2 Bentuk I Nyoman Sudana

Bentuk Degeng (1999:33) dikembangkan dengan berpijak pada variable-variabel yang mempengaruhi pembelajaran yaitu: kondisi pembelajaran, metode pembelajaran dan hasil pembelajaran. Keterkaitan antar komponen dalam system pembelajaran diformulasikan dalam langkah-langkah desain pembelajaran. Langkah-langkah tersebut adalah sebagai berikut: 1) Analisis tujuan dan karakter bidang studi; 2) Analisis sumber belajar (kendala); 3) Analisis karakter pelajar; 4) Menetapkan tujuan belajar dari isi pembelajaran; 5) menetapkan strategi pengelolaan pembelajaran dan 8) mengadakan pengembangan prosedur pengukuran hasil pembelajaran.

3 Bentuk Sugiyono

Kerangka pengembangan bentuk Sugiyono memberikan acuan dasar sebelum proses pengembangan itu dilakukan. Kerangka dasar pengembangan bahan ajar yang dikemukakan oleh Sugiyono ini mengemukakan 10komponen pengembangan sistem pembelajaran. Adapun kerangka tesebut meliputi sebagai berikut: 1) potensi dan 
masalah; 2) pengumpulan data; 3) Desain produk; 4) Validasi desain; 5) revisi desain; 6) ujicoba produk; 7) revisi produk; 8) ujicoba pemakaian; 9) revisi produk; dan 10) produk massal.

Berdasarkan pendapat para ahli di atas, maka peneliti dalam melaksanakan penelitian pengembangan bahan ajar materi bola voli di Sekolah Menengah Atas Negeri 16 Kota Banda Aceh, peneliti melakukan langkah-langkah pengembangan bahan ajar menurut Sugiyono yang melalui beberapa tahapan sehingga nantinya terciptalah suatu produk.

Langkah-langkah bahan ajar menurut Sugiyono ( 2012:298 ) sebagai berikut:

1) Potensi dan Masalah

Penelitian dapat berangkat dari adanya potensi dan masalah. Potensi adalah segala sesuatu yang bila didayagunakan akan memiliki nilai tambah. Masalah adalah pengimpangan antara yang diharapkan dengan yang terjadi. Masalah dapat diatasi melalui penelitian pengembangan dengan cara meneliti sehingga dapat ditemukan suatu model, pola atau sistem penanganan terpadu yang efektif yang dapat digunakan untuk mengatasi masalah tersebut.

2) Mengumpulkan informasi

Setelah potensi dan masalah dapat ditunjukkan secara factual dan up to date, maka selanjutnya perlu dikumpulkan berbagai informasi yang dapat digunakan sebagai bahan untuk perencanaan produk sesuatu yang diharapkan dapat mengatasi masalah tersebut.

3) Desain produk

Dalam bidang pendidikan, penelitian pengembangan penelitian menghasilkan produk yang diharapkan dapat meningkatkan produktivitas pendidikan yaitu lulusan yang berkualitas dan relevan dengan kebutuhan. Produk pendidikan misalnya kurikulum yang spesifik untuk keperluan pendidikan tertentu, metode mengajar, media pendidikan, buku ajar, modul, ompetensi tenaga kependidikan, sistem evaluasi dan lain-lain.

4) Validasi Desain

Validasi desain merupakan proses kegiatan untuk menilai apakah rancangan produk itu secara rasional baik atau efektif. Dikatakan secara rasional, karena validasi disini masih bersifat penilaian berdasarkan pemikiran rasional, belum fakta di lapangan.

\section{5) Revisi Desain}

Desain produk yang telah divalidasi oleh para pakar, maka akan terlihat dimana terdapat kelemahannya, sehingga kelemahan tersebut dapat diperbaiki sesuai dengan arahan dari pakar agar desain produk tersebut siap untuk diujicobakan.

6) Uji Coba Produk

Setelah desain produk diperbaikki, maka produk tersebut siap diujicoba dilapangan. Apabila produk telah diujicoba, maka terlihat apakah produk tersebut telah memenuhi syarat untuk diproduksi secara masal. Ketika produk tersebut masih terdapat kelemahan dan kendala maka selanjutnya akan direvisi lagi.

7) Revisi Produk

Apabila produk telah diujicoba, maka terlihat apakah produk tersebut telah memenuhi syarat untuk diproduksi secara masal. Ketika produk tersebut masih terdapat kelemahan dan kendala maka selanjutnya akan direvisi lagi.

8) Uji Coba Pemakaian

Apabila dalam pengujian produk didapat hasil yang kurang memuasakan maka dapat direvisi lagi dan setelah direvisi maka perlu diujicobakan lagi.

9) Revisi Produk

Revisi produk dilakukan apabila dalam pemakaian peda lembaga yang lebih luas tedapat kekurangan dan kelemahan. Dalam uji pemakaian, sebaiknyan pembuat produk selalu mengevaluasi bagaimana kinerja produk. Evaluasi dilakukan untuk mengetaui kelemahan-kelemahan yang ada sehingga dapat digunakan untuk penyempurnaan dan pembuatan produk baru lagi.

10) Produksi Masal

Pembuatan produk masal dilakukan apabila produk yang telah diujicoba dinyatakan efektif dan layak untuk diproduksi masal.

Berdasarkan pendapat yang telah dikemukakan di atas, dapat penulis rangkum bahwa pentingnya bahan ajar dalam kurikulum. Hal tersebut dianggap sebagai salah satu komponen kurikulum yang terkait dengan keberadaan bahan ajar dan kurikulum yang dinamis, sehingga bahan ajar itu sengaja dirancang dan dibuat untuk mempermudah dalam melakukan proses pengajaran yang dilakukan oleh pendidik yang dilakukan sesuai dengan kebutuhan para siswa yang akan diajarkan, sebab bahan ajar itu dipakai sebagai dasar yang menjadi sumber rujukan untuk pengajar yang diberikan kepada siswa dalam rangka mencapai tujuan dari proses belajar mengajar yang telah ditentukan sebelumnya. 


\section{Pengertian Bahan Ajar}

Kamus besar bahasa indonesia, bahan ajar dapat didefinisikan sebagai segala sesuatu yang dapat dipakaiatau diperlukan untuk digunakan sengan tujuan tertentu seperti sebagai pedoman, acuan danpegangan seseorang didalam melakukan proses mengajar, atau untuk memberi ceramah ( Moeliono, 1989:65 ), sedangkan untuk istilah bahan ajar sering diidentikkan dengan bahan kurikulum, bahan pelajaran, bahan mengajar. Bahan ajar atau bahan kurikulum ini pada hakikatnya dapat dilakukan dengan observasi dan bukan hanya merupakanide-ide yang bersifat abstrak untuk pedoman dalam mengajar. Disisi lain komponen isi dalam kurikulum sebenarnya berupa materi yang di programkan untuk mencapai tujuan pendidikan yang telah direncanakan sebelumnya ( Subandijah, 1992:5 ). Penyesuaian bahan ajar dengan kebutuhan masyarakat yang akan disampaikan pada siswa, berarti memberi peluang pada kurikulum agar tetap berkembang,terutama yang berguna pada bahan ajar.

Pengembangan bahan ajar itu bagian dari kurikulum, dan dianggap langkah praktis kerena melayani, menyiapkan materi dan pengalaman belajar siswa. Pengembangan kurikulum itu merupakan pengembangan komponen kurikulum yang berbentuk sistem itu sendiri, yaitu tujuan, bahan, metode, peserta didik, pendidik, media dan lingkungan. Menurut istilah lain dapat dijelaskan bahwa pengembangan bahan ajar merupakan salah satu bagian dalam usaha-usaha yang dilakukan untuk terus melakukan pengembangan terhadap kurikulum secara keseluruhan ( Nurgianto, 1988:83 ). Menurut Nurgianto ( 1988:84) bahan ajar tersebut dapat berperan dan bertujuan untuk:

1. Siswa dapat belajar sendiri tanpa harus ada guru atau teman siswa yang lain dalam belajar.

2. Siswa dapat belajar kapan saja dan dimana saja, sesuai dengan yang dikehendaki.

3. Siswa dapat belajar sesuai dengan kemampuannya sendiri.

4. Siswa dapat belajar menurut urutan yang dipilihnya sendiri.

5. Membantu potensi siswa untuk menjadi pelajaran sendiri.

Berdasarkan kesimpulan diatas dapat penulis simpulkan bahwa bahan ajar merupakan acuan yang dapat dugunakan dalam pembelajaran oleh pendidik. Bahan ajar dalam kurikulum juga merupakan konsep-konsep yang diberikan untuk memudahkan dan membantu anak mengerti hakikat ilmu yang terdapat dalam bahan ajar tersebut, sehingga pembelajaran pada pencapaian tujuan pembelajaran. Adanya bahan ajar dapat memudahkan siswa belajar disana saja, bisa belajar sesuai dengan kemampuannya dan dapat juga memberikan peluang kepada siswa belajar mandiri.

\section{Tujuan Pembelajaran}

Bahan ajar yang dikembangkan dalam pembelajaran memiliki tujuan untuk meningkatkan kebugaran jasmani siswa, meningkatkan sosial antar sesama siswa, mampu melakukan gerakan yang tepat, mampu bergerak dalam pembelajaran, kesesuaian materi terhadap bahan ajar yang dikembangkan, mampu meningkatkan kegembiraan pada siswa, menghindari kesulitan dan resiko cedera siswa dalam mempergunakan bahan ajar dan mampu meningkatkan keberanian siswa dalam bergerak.

\section{PROSEDUR PENELITIAN Pendekatan Penelitian}

Pada proses penelitian hendaknya dapat menetukan suatu metode penelitian yang akan digunakan, hal ini berdasarkan pada suatu pemahaman bahwa metode penelitian dapat dijadikan suatu cara atau langkah untuk memperoleh suatu data, menganalisi data, sehingga pada akhirnya akan mendapatkan hasil dari sasaran serta tujuan penelitian yang dilakukan. Dalam mencapai tujuan yang diinginkan pada penelitian yang dilakukan maka penting sekali bagi peneliti untuk memilih metode penelitian yang tepat sebagai metode penelitian yang akan dipakai.

Penggunaan metode penelitian sangat tergantung kepada permasalahan yang akan dibahas, hal ini dapat diartikan bahwa penggunaan suatu metode penelitian dapat dilihat dari segi efektivitas, efesiensi, serta relevansinya metode penelitian tersebut dengan permasalahan padasebuah penelitian yang dilakukan. Metode penelitian dikatakan efektif dalam hal ini dapat diartikan bahwa selama pelaksanaan penelitian dapat terlihat adanya suatu perubahan positif ke arah tujuan yang diharapkan. Sedangkan apabila dalam pelaksanaan penelitian penggunaan waktu, fasilitas, biaya, dan tenaga dapat terlaksana dengan sehemat mungkin akan tetapi tujuan penelitian tetap tercapai maka metode tersebut 
dapat dikatakan efisien dalam sebuah penelitian. Selanjutnya penelitian dapat dikatakan relevan apabila penelitian tersebut berjalan dengan lancar serta dapat menghasilkan hasil sesuai dengan tujuan penelitian serta adanya kesesuaian antara waktu penggunaan hasil pengolahan dengan tujuan yang akan dicapai pada suatu penelitian tidak terjadi penyimpangan.

Pendekatan dalam penelitian ini adalah metode penelitian ini adalah jenis penelitian pengembangan yang biasanya disebut research and development. Menurut Borg \& Gall (1983:774)penelitian dan pengembangan adalah suatu proses yang digunakan untuk mengembangkan atau memvalidasi produkproduk yang digunakan dalam pendidikan pembelajaran. Selanjutnya disebutkan bahwa prosedur penelitian dan pengembangan pada dasarnya terdiri dari dua tujuan utama, yaitu : (1) mengembangkan produk, dan (2) menguji keefektifan produk dalam mencapai tujuan.

Dalam penelitian ini model pengembangan yang digunakan adalah model pengembangan prosedural, karena model ini bersifat deskriptif, yaitu suatu prosedur yang menggariskan langkah-langkah yang harus diikuti dalam menghasilkan produk. Menurut Dwiyogo (2004:6) dalam setiap pengembangan dapat memilih dan menemukan langkah yang paling tepat bagi penelitiannya berdasarkan kondisi dan kendala yang dihadapi.

\section{Rancangan Penelitian}

Berdasarkan permasalahan yang dikaji oleh peneliti dan tujuan penelitian sebagaimana yang telah diuraikan di atas, maka untuk mencapai suatu tujuan dari penelitian ini diperlukan sebuah rancangan penelitian. Rancangan penelitian atau desain penelitian adalah rancangan yang dibuat oleh peneliti, sehingga rancangan tersebut merupakan konsepkonsep kegiatan yang akan dilaksanakan. Adapun rancangan yang terdapat dalam pelaksanaan penelitian ini dapat dijelaskan dengan menggunakan rancangan penelitian yang dikemukakan oleh Sugiyono. Rancangan penelitiannya sebagai berikut:

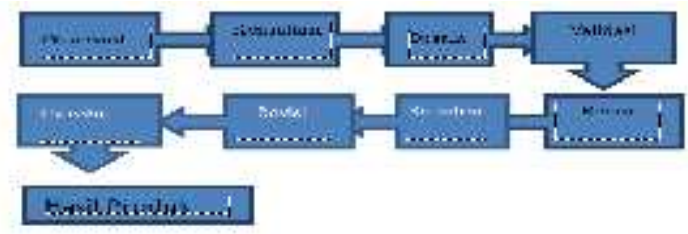

Tahapan Rancangan Pengembangan Bahan Ajar Yang Dikembangkan

1. Observasi

Observasi adalah pengamatan langsung yang dilakukan peneliti dalam menentukan permasalahan untuk pengumpulan data dan informasi pada pembelajaran penjasorkes materi bola voli untuk siswa Sekolah Menengah Atas.

2. Konsultasi Kepada Para Ahli

Setelah melakukan observasi, peneliti menjumpai para ahli yang terdiri dari rancangan, ahli isi,dan ahli media untuk melakukan konsultasi agar mendapat bimbingan dan saran terhadap permasalahan yang ditemukan pada pembelajaran Penjasorkes materi bola voli untuk siswa Sekolah Menengah Atas.

\section{Desain Produk}

Produk yang nanti dihasilkan dalam penelitian sesuai permasalahan apa yang ingin ditemukan dan diatasi. Desain produk baiknya duwujudkan dalam bentuk gambar dan pelaksanaan produk,sehingga dapat digunakan sebagai suatu pegangan yang diperlukan untuk menilai dan membuatnya.

\section{Validasi Desain}

Validasi desain produk dapat dilakukan dengan cara menghadirkan beberapa ahli rancangan, ahli isi, dan ahli media. Setiap para ahli diminta untuk menilai produk baru yang dirancang tersebut, sehingga nantinya dapat diketahui apa saja kelemahan dan kelebihan desain produk tersebut.

\section{Revisi Desain}

Desain produk yang telah divalidasi oleh para ahli, maka akan terlihat dimana terdapat kelemahannya, sehingga kelemahan tersebut dapat diperbaiki, sesuai dengan bimbingan dan saran dari parah ahli agar desain produk tersebut siap untuk disimulasikan.

\section{Simulasi Produk}

Setelah desain produk diperbaiki, maka produk tersebut siap untuk disimulasikan oleh peneliti kepada 20 siswa kelas XI Sekolah Menengah Atas, apabila produk telah disimulasikan, maka akan terlihat kelemahan dan kendala produk tersebut.

\section{Revisi Produk}

Apabila produk yang disimulasikan mengalami kelemahan atau kendala, maka produk tersebut direvisi kembali sesuai dengan bimbingan dan saran dari para ahli,agar desain produk tersebut siap untuk diuji coba pemakaiannya.

8. Uji Coba Pemakaian Produk 
Setelah direvisi maka dilakukan uji coba pemakaian produk kembali oleh peneliti dengan disaksikan langsung oleh para ahli, terdapat produk yang telah direvisi dengan harapan dapat menangani kelemahan dari produk yang dihasilkan tersebut,sehingga nantinya produk tersebut memiliki kelayakan untuk digunakan.

9. Hasil Produk

Hasil produk yang telah dilakukan uji coba pemakaiannya oleh siswa Sekolah Menengah Atas, produk telah memenuhi syarat untuk pemakaian sesuai bimbingan, maka produk yang dihasilkan sudah layak untuk digunakan bagi guru penjasorkes dalam pembelajaran materi bola voli di Sekolah Menengah Atas.

\section{Subjek Penelitian}

Subjek penelitian adalah segala sesuatu yang menjadi objek dari suatu penelitian ( Arikunto, 2004:130 ). Berdasarkan kutipan diatas, yang menjadisubjek dalam pelaksanaan penelitian penegmbangan bahan ajar materi bola voli ini adalah siswa dan siswi kelas XI Sekolah Menengah Atas Negeri 16Kota Banda Aceh.

\section{Instrumen Penelitian}

Hasil belajar permainan bola voli

a) Definisi Konseptual

Hasil belajar adalah kemampuan keterampilan, sikap dan keterampilan yang diperoleh siswa setelah ia menerima perlakuan yang diberikan oleh guru sehingga dapat mengkonstruksikan pengetahuan itu dalam kehidupan sehari-hari.

b) Definisi Operasional

Hasil belajar yang dimaksud disini adalah hasil belajar permainan bola voli. Skor atau nilai yang diperoleh oleh siswa dari tes tulis yang dilakukan setelah menerima materi. Hasil belajar merupakan interaksi kemampuan pelajaran.

\section{Teknik Pengumpulan Data}

Adapun teknik pengumpulan data dalam penelitian ini menggunakan beberapa tahapan, sebagai berikut:

\section{Validasi Desain}

Validasi desain merupakan proses kegiatan untuk menilai apakah rancangan produk, dalam hal ini sistem kerja baru secara rasional akan lebih efektif dari yang lama atau tidak ( Sugiyono, 2012:302 ).validasi desain dalam penelitian ini dengan menghadirkan beberapa para ahli yang sudah berpengalaman dalam menilai produk yang baru di rancang.
Setelah para ahli menilai, sehingga selanjutnya dapat diketahui kelemahan dan kekuatan desain produk tersebut. Validasi desain dapat dilakukan dalam forum diskusi dengar para ahli yang sebelumnya peneliti mempresentasikan terlebih dahulu melakukan desain produk tersebut.

\section{Ujicoba Produk}

Setelah desain divalidasi oleh para ahli, selanjutnya sebelum peneliti melakukan ujicoba produk tersebut maka terlebih dahulu peneliti menghasilkan produk yang akan di ujicoba. Setelah dihasilkan produk, maka barulah bisa melakukan ujicoba produk. Ujicoba produk pada penelitian ini diakukan pada sampel penelitian yaitu 20 orang siswa kelas XI Sekolah Menengah Atas Negeri 16 Kota Banda Aceh.

3 Validasi Produk

Ujicoba produk yang telah dilakukan, jika terdapat kelemahan maka produk selanjutnya divalidasi oleh para ahli,sehingga produk yang dihasilkan menjadi lebih baik dan siap untuk digunakan.

\section{HASIL PENELITIAN DAN PEMBAHASAN}

Proses pengembangan bahan ajar materi permainan bola voli untuk siswa SMA N 16 Kota Banda Aceh melalui beberapa tahapan dalam pengumpulan item-item baru dengan langkah-langkah sebagai berikut: 1) Observasi; 2) Konsultasi para ahli; 3) Desai produk; 4) Validitas desain; 5) Revisi desain; 6) Simulasi produk; 7) Revisi produk; 8) Uji coba pemakaian produk; 9) Hasil produk. Setelah kesembilan tahapan tersebut selesai akan dapat item-item bahan ajar materi bola voli yang akan dikembangkan dan di ujicoba, kemudian hasil dianalisis dengan pengujuan validitas, reabilitas, analisis faktor. Dari hasil pengujian bahan ajar bola voli tersebut akan dijelaskan sebagai berikut:

1 Validitas

Berdasarkan hasil pengujian data, maka hasil validasi pakar memperoleh hasil validasi yang pertama rancangan 13 item pertanyaan dengan hasil yang baik, sedangkan hasil uji coba yang terdiri dari 13 item pertanyaan terhadap 20 sempel yaitu siswa sebagai subjek ternyata memiliki tingkat validitas yang tinggi, yang kesemuanya mempunyai tingkat validitas yang sedang hal ini mengacu pada kriteria yang ditemukan oleh Morehause, Stull dan Bergemen dalam Sugiono, (2012:172) bahwa 000- \pm 200 derajat validitas sangat rendah, 200- \pm 400 derajatvaliditas rendah, 400- \pm 600 derajat validitas sedang, 600- \pm 800 derajat validitas 
tinggi, dan $800- \pm 1000$ derajat validitas sangat tinggi, disamping itu juga diperoleh nilai validitas lebih kecil dari 0,030,ketiga belas item dalam pengenbangan bahan ajar bola voli untuk SMA N 16 Kota Banda Aceh memiliki tingkat validitas yang tinggi.

\section{Reabilitas}

Berdaasarkan hasil pengujian reabilitas pengembangan bahan ajar materi permainan bola voli untuk SMA N 16 Kota Banda Aceh, ternyata memiliki tingkat reabilitas yang tinggi, ini diperoleh dri hasil ke 4 validator.

Berdasarkan uraian diatas secara keseluruhan bahan ajar permainan bola voli ternyata memiliki tingkat validitas tinggi sehingga dapat dijadikan sebagai salah satu bahan ajar untuk materi permainan bola voli untuk SMA. Rentang validitas serta reabilitas yang tinggi dianggap wajar, karena proses tahapan pengembangan bahan ajar bola voli dan uji coba langsung terhadap siswa yang menjadi subjek peneliti. Hasil presentase sehubungan dengan konstruk bahan ajar permainan bola voli hasil validator rancangan oleh pakar.

\section{KESIMPULAN}

\section{Kesimpulan}

Berdasarkan hasil penelitian dan pembahasan yang telah dilakukan oleh peneliti yang sudah dibahas dalam bagian pembahasan maka penulis dapat merumuskan bahwa angka bahan ajar permainan bola voli untuk siswa SMA N 16 Kota Banda Aceh yang sudah divalidasi oleh para ahli dari 13 item pertanyaan semua dapat diikut sertakan dalam bahan ajar bola voli karena memiliki tingkat kesahihan yang tinggi dengan memperoleh nilai indeks validitas 0,851 , sehingga dapat digunakan untuk bahan pembelajaran materi bola voli untuk siswa Sekolah Menengah Atas dan memiliki tingkat kehandalan yang tinggi dengan perolehan nilai indeks reabilitas 0,685 .

Dengan demikian derajat bahan ajar yang validitas dan reabilitas sangat tinggi sehingga bahan ajar bola voli ini dapat diterapkan di sekolah-sekolah menengah atas pada saat mengajar materi bola voli.

\section{DAFTAR PUSTAKA}

Amir, Nyak. 2010. Psikologi Olahraga. BandaAceh: CV. Marzalia Press ,2010. Pengukuran Dan EvaluasiKinerja Olahraga. Banda Aceh: Syiah Kuala University Press
Arikunto, Suharsimi. 1994. Prosedur Penelitian: Suatu Pendekatan Praktek. Bandung: Rineka Cipta.

Borg and Gall. 1988. Research Evaluation. Boston:Allyn and Bacon.

Degeng, I.N.S. 1999. Rancangan Pembelajaran. Teori dan Teknik Pembelajaran. Malang: Universitas Kristen Cipta Wacana.

Depdiknas (2010). Undang-Undang Nomor 14 Tahun 2005 Tentang Guru dan Dosen. [Online]. Tersedia: http://www.depdiknas.go.id

Desember 2007]

Departemen Pendidikan Nasional. (2001). Kamus Besar Bahasa Indonesia. Jakarta: Balai Pustaka.

Dieter Beutelstahl. 1986. Belajar Bermain Bola. Bandung: Pioner Jaya.

http:// Responsitory. UPI/3524/6/s_Jkt_0801467_Chapter 3 Pdf Sugiono (2012 : 172).

Kosasih, Engkos. (1984). Olahraga Teknik dan Program Latihan. Jakarta: PT. Akamedika Presindo.

Moeliono. 1989. Kamus Besar Bahasa Indonesia. Jakarta: Depdikbud, Balai Pustaka.

Poerwadarminto. 2003. Kamus Besar Bahasa Indonesia. Jakarta: Balai Pustaka.

M. Yunus. 2000. Bola Voli Olahraga Pilihan. Jakarta: Depdikbud Direktorat Jenderal Pendidikan Tinggi.

Nurgiyanto. 1988. Dasar-Dasar Pengembangan Kurikulum. Sebuah Pengantar Teori dan Pelaksanaan. Yogyakarta: BPFE.

Nugroho. 2005. Strategi Jitu Memilih Metode Statistik Penelitian dengan SPSS. Yogyakarta: Andi Yogyakarta.

Ridwan. 2011. Dasar-Dasar Statistika. Bandung: Alfabeta. 
Subandijah. 1992. Pengembangan dan Inovasi Kurikulum. Jakarta: Rajawali Press

Sugiyono. 2012. Metode Penelitian Kombinasi. $\mathrm{Z}$

Syarifuddin, AIP. 1997. Pengetahuan Olahraga. Jakarta: CV. Baru.

Suharno, HP. 1982. Metodologi Pelatihan Bola Voli. Yogyakarta: IKIP Yogyakarta.

Syarifuddin. 1997. Pokok-Pokok Pengembangan Pendidikan Jasmani dan Kesehatan. Jakarta: Depdikbud.
Tim Pengembangan MKDP. 2013. Kurikulum dan pembelajaran. Jakarta: Rajawali Press.

Tim Program Studi MPO. 2012. Panduan Tesis. Banda Aceh: PPs Unsyiah.

Thomlinson (1998:2). Materials Development in Languege Teaching. Cambridge: Cambridge University Press.

Toto. 2002. Pendekatan Keterampilan Taktis dalam Pembelajaran. Jakarta: Departemen Pendidikan Nasional.

Verducci, F.M. 1980. Measurement Concept in Physical Education. New York: Mosby Company. 